\title{
Interventions to reduce HIV/AIDS stigma: What have we learned?
}

Lisanne Brown

Lea Trujillo

Kate Macintyre

Follow this and additional works at: https://knowledgecommons.popcouncil.org/departments_sbsr-hiv

Part of the Diseases Commons, and the International Public Health Commons How does access to this work benefit you? Let us know!

\section{Recommended Citation}

Brown, Lisanne, Lea Trujillo, and Kate Macintyre. 2001. "Interventions to reduce HIV/AIDS stigma: What have we learned?" Horizons Report. Washington, DC: Population Council. 


\section{Hgrizons}

\section{Interventions to Reduce HIVIAIDS Stigma:}

What Have We Learned?

Horizons Program

Tulane University 


\title{
Interventions to Reduce HIV/AIDS Stigma: What Have We Learned?
}

\author{
Lisanne Brown', Lea Trujillo², Kate Macintyre ${ }^{2}$
}

\footnotetext{
${ }^{1}$ Horizons Program/Tulane School of Public Health and Tropical Medicine, New Orleans, Louisiana

2 Tulane School of Public Health and Tropical Medicine, New Orleans, Louisiana
} 
USAID This study was supported by the Horizons Program and Tulane University. Horizons is funded by the U.S. Agency for International Development, under the terms of HRN-A-00-97-00012-00. The opinions expressed herein are those of the authors and do not necessarily reflect the views of the U.S. Agency for International Development.

Published in September 2001.

The Population Council is an international, nonprofit, nongovernmental (2) Population Council institution that seeks to improve the wellbeing and reproductive health of current and future generations around the world and to help achieve a humane, equitable, and sustainable balance between people and resources. The Council conducts biomedical, social science, and public health research and helps build research capacities in developing countries. Established in 1952, the Council is governed by an international board of trustees. Its New York headquarters supports a global network of regional and country offices.

Copyright (C) 2001 The Population Council Inc. 


\section{Table of Contents}

Executive Summary 1

Introduction 3

$\begin{array}{ll}\text { Background } & 4\end{array}$

$\begin{array}{ll}\text { Methods } & 7\end{array}$

Results $\quad 8$

Review of interventions to reduce AIDS stigma $\quad 8$

Review of interventions to reduce stigma related to 12

diseases other than AIDS

$\begin{array}{lc}\text { Summary and Implications } & 14\end{array}$

$\begin{array}{ll}\text { Implications for interventions } & 14\end{array}$

$\begin{array}{ll}\text { Recommendations for future research } & 15\end{array}$

$\begin{array}{ll}\text { Bibliography } & 17\end{array}$

$\begin{array}{ll}\text { Tables } & 23\end{array}$

Table 1 Summary of HIV/AIDS stigma intervention studies 23

Table 2 Types of interventions $\quad 30$

Table 3 Summary of non-HIV/AIDS stigma intervention studies 31 


\section{Executive Summary}

Stigma is a common human reaction to disease. Throughout history many diseases have carried considerable stigma, including leprosy, tuberculosis, cancer, mental illness, and many STDs. HIV/AIDS is only the latest disease to be stigmatized.

This paper reviews 21 interventions that have explicitly attempted to decrease AIDS stigma both in the developed and developing countries and 9 studies that aim to decrease stigma related with other diseases. The studies selected met stringent evaluation criteria in order to draw common lessons for future development of interventions to combat stigma. This paper assesses published and reported studies through comparison of audiences, types of interventions, and methods used to measure change.

Target audiences include both those living with or suspected of living with a disease and perpetrators of stigma. All interventions reviewed target subgroups within these broad categories. Types of programs include: general information-based programs, contact with affected groups, coping skills acquisition, and counseling approaches. A limited number of scales and indices were used as indicators of change in AIDS stigma.

\section{Key Results}

- While it may be unrealistic to think that we can eliminate stigma altogether, the studies reviewed here show that we can do something about stigma and that it can be reduced through a variety of intervention strategies including information, counseling, coping skills acquisition, and contact.

- Among studies with a control or comparison group that received the standard of careinformation only - adding another intervention strategy such as counseling or coping skills acquisition was effective in changing attitudes and behaviors. While the added interventions as a whole reduced stigma when compared to control or comparison groups, those studies that tested several different modes of the same strategy (e.g., different approaches to providing information or coping skills acquisition) generally found no differences between intervention groups.

- Many of the interventions tried in developing countries were community-based, compared to most of the interventions in the United States, which were aimed at individuals (students or the assumed "at-risk" subgroups). This may partly be a reflection of the types of strategies tested, but this preference given to community-based approaches in developing countries may reflect an understanding that stigma must be dealt with at both a collective and individual level. In many parts of sub-Saharan Africa, where many of the studies reviewed took place, everyone is at risk.

- The majority of interventions that took place in developing countries were not evaluated rigorously. Cross-sectional data, non-probability, and small convenience samples were often 


\section{Hgrizons}

used to try to measure change in attitudes or beliefs. It is generally not possible to tell from the studies how stigma is being measured. Two studies use a stigma-scale to measure the concept of "tolerance" toward an HIV-positive person. Several other studies assessed tolerance through hypothetical situations such as willingness to sit beside/eat with/share utensils with a person living with HIV/AIDS (PLHA).

- Finally, few studies assessed sustained changes in stigma-related attitudes and behaviors over time. Most post-intervention tests were conducted immediately after the intervention, and none of the studies looked at the possible long-term impact of the interventions.

\section{Recommendations for Future Research}

This review identifies the following gaps in our knowledge of how to reduce stigma:

- First, relatively few interventions to reduce AIDS stigma have been conducted (or at least rigorously evaluated, documented, and published) in developing countries. Many more interventions need to be tested. If future research is to benefit and learn from past interventions, the results of these studies need to be widely disseminated.

- Second, not all types of interventions have been tested in all settings or populations. For example, inducing empathy for PLHA through direct contact has proven successful in reducing stigma and increasing positive attitudes in the United States However, we do not know much about how well this approach works in developing countries. Consider, for example, how many PLHA there are living in many communities in Africa, and yet stigma remains despite their presence.

- The authors were surprised to find only two examples of national level effects (and only one in India that was truly a national campaign) to combat stigma. We expected to find more studies on the effect of mass media campaigns on stigma, but if they do exist, they have not been documented in the published literature.

- This review tells us that stigma can be reduced, at least in the short term and on a small scale. But we need programs that scale up efforts to combat stigma. We need evidence of comprehensive programs that use multiple channels and target entire communities including health workers and PLHA. In such comprehensive programs, once stigma has been reduced, does it remain at a low level? Another gap appears to be the few interventions targeting the young.

- Finally, the increased access to drugs within the context of developing countries may have important effects on stigma and must be documented. In effect "What drives stigma" is an especially important and complex question given the rapidly changing and dynamic situation that surrounds the epidemic. 


\section{Introduction}

Stigma and discrimination relating to HIV/AIDS (AIDS stigma) undermines public health efforts to combat the epidemic (Malcolm et al. 1998; UNAIDS 2000a, 2000b?). AIDS stigma negatively affects preventive behaviors such as condom use, HIV test-seeking behavior, care-seeking behavior upon diagnosis, quality of care given to HIV-positive patients, and perception and treatment of PLHA by communities, families, and partners (Gerbert et al. 1991; Herek 1990; Herek and Glunt 1988). One of the most surprising elements of AIDS stigma is its ubiquitous nature even where the epidemic is widespread and affecting so many people, such as in sub-Saharan Africa. Therefore, as many in the HIV/AIDS community note, decreasing AIDS stigma is a vital step in stemming the epidemic (Cameron 2000; Goldin 1994; Malcolm et al. 1998; UNAIDS 2000b). Given this situation, it is critical that interventions that effectively reduce AIDS stigma be identified and implemented.

The objectives of this paper are to describe those interventions aimed at decreasing AIDS stigma, summarize common characteristics and audiences, and identify which aspects of these interventions have proven successful. In addition, we summarize lessons learned from designing, testing, implementing, measuring, and evaluating programs to reduce AIDS stigma. We have intentionally maintained a global perspective, though the majority of the studies reviewed in this paper are stigma-reduction initiatives in the United States. But with 90 percent of the burden of disease in poor, less developed nations the imperative of international public health must be to search for, test, and implement strategies that reduce stigma in these countries.

Stigma is often mentioned together with discrimination, but in this paper we focus on stigma as a separate phenomenon to merit separate interventions. We do recognize, however, that the two concepts are related and often interdependent. 


\section{Hgrizons}

\section{Background}

The HIV/AIDS pandemic has evoked a wide range of reactions from individuals, communities, and even nations, from sympathy and caring to silence, denial, fear, anger, and even violence. Stigma is an important factor in the type and magnitude of the reactions to this epidemic (Malcolm et al. 1998). We know much less about the level and reasons for silence and denial than we know about violent, hostile, or isolationist reactions. Physical harm of PLHA has been documented in the United States (North and Rothenberg 1993; Rothenberg and Paskey 1995; Sowell et al. 1999; Zierler et al. 2000) and in numerous reports from developing countries (Ogunyombo 1999). Probably one of the most publicized events occurred in a Durban township in 1998, when Gugu Dlamini, an AIDS activist, was killed by members of her community for openly disclosing her HIV status. While this is not an isolated event, it highlights the potential consequences of AIDS stigma, and points to the collective and communal as well as the individual level of involvement necessary to reduce stigma.

Goffman (1963) defines stigma as an undesirable or discrediting attribute that an individual possesses, thus reducing that individual's status in the eyes of society. Stigma can result from a particular characteristic, such as a physical deformity, or it can stem from negative attitudes toward the behavior of a group, such as homosexuals or prostitutes. Under Goffman's definition, stigmatization is the societal labeling of an individual or group as different or deviant. Others have defined stigma as social processes that are linked to societal power structures (Link 2001; Parker 2001).

Several authors divide stigma into felt or perceived stigma and enacted stigma. (Jacoby 1994; Malcolm et al. 1998; Scrambler 1998; Scrambler and Hopkins 1986). Felt stigma refers to real or imagined fear of societal attitudes and potential discrimination arising from a particular undesirable attribute, disease (such as HIV), or association with a particular group. For example, an individual may deny his/her risk of HIV, refuse to use condoms, or refuse to disclose HIV status for fear of the possible negative reactions of family, friends, and community. Enacted stigma, on the other hand, refers to the real experience of discrimination. For example, the disclosure of an individual's HIV-positive status could lead to loss of a job, health benefits, or social ostracism. Felt stigma can be seen as a survival strategy to limit the occurrence of enacted stigma, such as when people someone deny their risk of infection or fails to disclose HIV status in order to avoid being ostracized.

Individuals who hold negative attitudes or who enact stigmatizing or discriminatory behavior have been referred to by some as the perpetrators of stigma and discrimination, whereas PLHA and those affected or associated with HIV are the targets (Herek and Capitanio 1998).

Stigmatization is a dynamic process that arises from the perception that there has been a violation of a set of shared attitudes, beliefs, and values. These can lead to prejudicial thoughts, behaviors, and/or actions on the part of governments, communities, employers, health care providers, coworkers, friends, and families (Cameron 1993; Jayaraman 1998; Zierler et al. 2000). Sources of stigma include fear of illness, fear of contagion, and fear of death. Fear of illness and fear of 
contagion is a common reaction among health workers, co-workers, and caregivers, as well as the general population. Stigma is one means of coping with the fear that contact with a member of an affected group (e.g. by caring for or sharing utensils with a PLHA) will result in contracting the disease (Meisenhelder and La Charite 1989).

Literature on care-giving shows that fear of contagion and fear of death have clear negative effects on health care workers' attitudes toward and treatment of PLHA (Gerbert et al. 1991; Kelly et al. 1987; Weinberger et al. 1992). These attitudes range from mild disdain, through outright refusal to treat, to outright abuse of PLHA. But it is important to recognize that stigma affects health workers themselves. A recent discussion on a global AIDS stigma listserv included the following comments:

"Health workers are expected to know, feel and act in certain ways. But who has prepared them for this HIV/AIDS? Many health workers have the same information the man on the street has. ... The disease is fatal! Who is not afraid of death? Health workers are in it day in day out. They have not been targeted for any special education program that is relevant to their situation. Knowledge and skills yes, that they have, it is part of many training programs. But what about preparing them to come to terms with their fears and anxieties about their own sexuality and mortality, their prejudices?" Florence Mhonie, Kenya (http://www.hdnet.org/home2.htm; stigma-aids: health care provider-17)

HIV-stigma is often layered on top of many other stigmas associated with such specific groups as homosexuals and prostitutes and such behaviors as injecting drug use and casual sex. These layers of stigma have unfortunately helped to extend and deepen the AIDS stigma to many who are infected with or affected by the disease (Herek 1993; Rushing 1995; Sontag 1990).

Consequences of stigma can be viewed along a continuum from mild reactions (e.g., silence and denial), to ostracism and ultimately violence. Research has shown that AIDS stigma can have a variety of negative effects on HIV test-seeking behavior, willingness to disclose HIV status, health care-seeking behavior, quality of health care received, and social support solicited and received (Boyd et al. 1999; King 1989; Malcolm et al. 1998; Raveis, Seigel, and Gorey 1998; Sowell et al. 1997).

Silence and denial may be the most pervasive reactions to stigma, as signified by the title of last year's International AIDS Conference: Breaking the Silence. For some individuals, not knowing one's HIV serostatus is far preferable to being tested (Cameron 2000). The fear is that the lack of confidentiality, which is highly likely in many settings, forces disclosure and that individuals can then face prejudice, discrimination, the loss of a job, strains on or the breakup of relationships, social ostracism, or violence. (Kayawe, Kelly, and Baggaley 1998; Macintyre, Brown, and Sosler 2001). All of this prevails when there is little treatment available for the majority of HIV-positive individuals in developing countries. As one commentator on the situation in Zimbabwe said recently, "Why should I go and get tested when I know for a fact I won't be able to get the necessary treatment?" Joshua Chigodora, Zimbabwe (http://www.hdnet.org/home2.htm; stigmaaids: Definition and Context - 19) 


\section{Hgrizons}

The way in which individuals discover and disclose their HIV status to others, as well as how they cope with their HIV status, is influenced by cultural and community beliefs and values regarding causes of illness, learned patterns of response to illness, social and economic contexts, and social norms (Mechanic 1995). Even when individuals suspect they are HIV-positive, they may not seek a test or treatment if it means going to a known AIDS clinic or a community doctor (Muyinda et al. 1997).

Although social support organizations for PLHA exist in both developed and developing countries, these organizations only help those infected or affected by HIV cope with stigma. Those affected by AIDS stigma are not only those individuals with or perceived as having HIV/AIDS, but include families, friends, and groups who work with the PLHA or those affected. There are few interventions that address the larger social causes of stigma. 


\section{Methods}

Researchers conducted a search of published and unpublished literature (e.g., conference presentations) to identify interventions that attempted to reduce AIDS stigma. They identified over 100 citations through key word searches using several databases including AIDSLINE, MEDLINE, SOCIOFILE, PSYCHINFO, and POPLINE. In the search, researchers included key words: HIV/AIDS, prejudice, stereotyping, stigma, intervention, reduction, health education, behavior change, and attitude change. The team conducted a subsequent search using combinations of these terms. They grouped each intervention identified through the searches according to study design. Researchers conducted a second search through the references of all the articles identified in the first wave.

The criteria for inclusion in the review were: (1) the study evaluated an intervention that included some component to reduce stigma of AIDS or other diseases, and (2) the study design was a randomized experiment or quasi-experimental with at least a post-intervention test. Using these criteria, researchers identified 21 intervention studies that attempted to reduce AIDS stigma. Of the 21 selected studies, the team could review 11 closely because they had been published in peerreviewed journals.

The remainder of the selected studies are abstracts presented primarily at international AIDS conferences. Researchers included the latter group in the review only after they made attempts to contact the authors to obtain reports or papers and to check databases to see if any papers had been published. Unfortunately these efforts were unsuccessful. Since all of the abstracts are from developing countries or involved subgroups from developing countries, and helped illustrate the range of different methods used to reduce stigma, the researchers decided to retain them for review. The researchers identified these abstracts throughout the paper. They identified an additional nine intervention studies that attempted to reduce stigma related to other diseases and reviewed them also. 


\section{Hgrizons}

\section{Results}

\section{Review of Interventions to Reduce AIDS Stigma}

The 21 studies that aimed to reduce AIDS stigma are reviewed on the following characteristics:

- Who was the target audience or population?

- Where did the study and intervention take place?

- What was the intervention?

- How effective was the intervention?

- How was the intervention evaluated (study design and methodology?).

It should be noted that the interventions presented in this review were not all aimed exclusively at reducing AIDS stigma, but involved many other components as well (i.e., increasing awareness and knowledge, promoting behavior change, and so forth). This review focuses on the stigma component within these more comprehensive interventions. Table 1 summarizes the results of the 21 studies.

\section{Target populations}

The studies are divided almost equally between developed and developing countries. Ten of the studies took place in developed countries: eight in the United States, one in Scotland, and one in Canada. Most of the developing country studies took place in eastern Africa. Not surprisingly, five took place in Uganda, a country that confronted the HIV/AIDS epidemic and the stigma associated with it early on. Two studies took place in Tanzania and one in Zimbabwe. Jamaican, Indian and Ethiopian immigrant communities in Israel were the sites for the remaining studies.

The majority of studies aimed to increase tolerance of PLHA among different segments or proxies of the general population. However, the target group, setting, and scale of these studies varied tremendously. Five of the U.S.-based studies and the Canadian study tested various strategies to increase empathy and altruism and reduce anxiety/fear of PLHA among small samples of psychology, physical therapy, and nursing undergraduate students (the majority of them volunteers) (Batson et al. 1997; Bean et al. 1989; Held 1992; Wyness, Goldston, and Trussler 1996). Another US-based study sought to improve attitudes toward PLHA among poor black women applying for certification in the Women, Infants, and Children (WIC) program in Augusta, Georgia (Ashworth et al. 1994).

Study researchers used community-based approaches that aimed to improve attitudes toward PLHA in Uganda (Mwandha and Were 1998) and among Ethiopian immigrants in Israel (Soskolne et al. 1993). The Zimbabwe study targeted commercial farmers and their employers (Kerry and Margie 1996) for a stigma reduction program. The Simpson study targeted pregnant women in Edinburgh, Scotland. Two studies promoted accepting attitudes among youth: primary school children in two 
regions of Tanzania, and youth in Jamaica (Hue and Kauffman 1998; Klepp et al. 1997). Finally, two studies targeted national samples through mass media to increase acceptance of PLHA, one in the U nited States and the second in India (Herek and Capitanio 1997; Venkataraman et al. 1996).

Two studies, one in Uganda and one in New York, aimed to help those at risk or infected by the disease cope with stigma. In Kampala, Uganda HIV-positive clients of The AIDS Support Organization (TASO) received counseling services to help them cope with the disease (Kaleeba et al. 1997). A study among at-risk asymptomatic adults recruited for HIV testing in New York City aimed to examine the effectiveness of psycho-educational interventions in reducing emotional distress after HIV testing (Perry et al. 1991).

Four studies targeted a combination of at-risk, infected, and/or general population groups in Uganda and Tanzania, both high HIV prevalence countries. Three of the studies conducted in Uganda target entire communities, including those who are HIV-positive. These studies aimed to decrease PLHA isolation and increase community cohesion. (Kiguli 1996; Kikonyogo et al. 1996; Nansubuga, Aneko and Kirega 1996). The Tanzania study targeted house-girls thought to be at high risk and their employers in Dar es Salaam, Tanzania (Mwambu 1998).

\section{Types of interventions}

The interventions tested in the 21 studies are grouped into 4 categories (see Table 2): informationbased approaches, coping skills acquisition, counseling approaches, and contact with affected groups. While several of the intervention strategies could be classified into several categories (e.g., media campaigns can be applied in all four categories) and can be applied to several target groups, for purposes of this review the researchers classified each intervention strategy into a single category. Some of the intervention strategies, such as coping skills acquisition, were often, but not exclusively, used with one audience: PLHA.

Multi-intervention or multi-channel approaches were common, based on the premise that the greater the number of channels the greater the effect. Other studies tested different strengths or modes of the same intervention strategy (e.g., different levels of intensity of providing information in order to test a dose-response effect). Generally in a multi-intervention study, the first group receives information or a combination of the standard of care (i.e., the standard post-HIV test counseling) plus the new information/educational component that is being tested. The next intervention group builds on the first by adding another type of intervention or, more usually, a deeper layer of information, with the aim of creating synergistic effects. Comparisons are then made between control and intervention groups and across interventions groups.

Information-based approaches are used in nearly all the interventions and therefore a range of target groups (often in combination with another strategy) and are generally didactic. The information can be delivered by advertisement, or through leaflets, information packs, or presentation in a class or lecture. The information presented often includes a factual description of the disease, transmission mode, and methods of risk reduction. 


\section{Hgrizons}

Four studies tested information-based approaches alone, one each in the United States, Jamaica, Tanzania, and Israel. (Ashworth et al. 1994; Hue and Kauffman 1998; Mwambu 1998; Soskolne et al. 1993). Overall these studies found positive effects (i.e., increased tolerance of PLHA) in comparison to control groups, if there was one. However, where more than one approach was tested there was no difference between intervention groups. For example, Ashworth et al. (1994) tested the provision of the same information in two different formats, a 15-minute videotape on AIDS and a standardized presentation of AIDS facts given by a black nurse educator, among poor black American women. This study found that compared to the control group, both experimental groups had a higher tolerance toward PLHA at both the immediate posttest and at the two-month follow-up, although no differential treatment effects were observed. In Jamaica and Israel, significant increases in positive attitudes toward PLHA were achieved through the provision of information provided through peer education, lectures, pamphlets, or workshops.

Five studies combined information-based approaches with counseling (Kaleeba et al. 1997; Kerry and Margie 1996; Kikonyogo et al. 1996; Nansubuga, Aneko and Kirega 1996; Simpson et al. 1998), a strategy used to provide praise and social support for positive attitudes, behavior change, or maintenance of safe behaviors. An example of this approach is a support group for PLHA, in which individuals receive personal support for resolving issues or situations with spouses, families, communities, and so forth, in a safe environment. All five information and counseling studies targeted their interventions at PLHA and those potentially at risk. Two studies focused on HIV testing, one to improve uptake of the HIV test among antenatal women in a Scottish hospital (Simpson et al. 1998) and the other to reduce emotional distress after having the HIV test (Perry et al. 1991). The latter used the counseling sessions for behavioral reinforcement and to teach coping skills acquisition. The interventions in both of these studies reduced anxiety and distress in the experimental groups as compared to controls, but there were no differential treatment effects across experimental groups. The interventions tested in the three remaining studies - two in Uganda and one in Zimbabwe - increased disclosure among PLHA and improved community attitudes compared with a baseline measure, although there were no control groups.

Interventions that attempted to teach potential perpetrators skills for diffusing conflicting situations were applied at the individual or small group level, because more instruction was required than a standard presentation of facts. The five studies conducted among small groups of psychology and other students tested these types of approaches. Master imagery and group desensitization are examples of coping skill acquisition techniques. In master imagery an individual is presented with a hypothetical situation where they have contact with a PLHA and is taught appropriate coping skills for resolving the situation. Group desensitization teaches relaxation training first, and then progressively exposes the individual or group to a number of situations in which there is exposure to PLHA, utilizing the newly learned relaxation techniques to decrease tension in a hypothetical situation.

Two studies used a combination of information and coping skill acquisition to increase positive attitudes toward PLHA among members of the general community. A study among primary school children in Tanzania used role-play and small group discussions in addition to factual information, with the hope that improving their knowledge, attitudes, and practices would have beneficial effects on the surrounding communities (Klepp et al. 1997). Using a randomized community trial, 
local teachers and health workers implemented a two- to three-month program consisting of AIDSrelated information, small group discussions about risk reduction, and student-created posters depicting perceptions of HIV risk factors. Attitudes toward PLHA among the school children at the 12-month follow-up significantly improved. The second study used information/coping skills acquisition strategy tested techniques to resolve negative feelings among physical therapy students in New York and increased their willingness to treat PLHA (Held 1992).

Contact with infected or affected groups was used alone or in combination with other approaches in seven studies (Batson et al. 1997; Bean 1989; Herek and Capitanio 1997; Mwandha and Were 1998; Venkataraman et al. 1996; Wyness, Goldstone, and Trussler 1996). Contact creates an environment in which the general population can interact with the stigmatized group, either directly or vicariously (e.g., through the media). The theory is that a more personal relationship with a PLHA, either through face-to-face conversations or hearing a testimonial from infected or affected individuals, will demystify and dispel misinformation and generate empathy, which in turn reduces stigma and prejudice(Allport 1954; Brewer and Miller 1984).

The Herek and Capitanio (1997) study was a natural intervention that looked at the effects of Earvin "Magic" Johnson's disclosure of his HIV status to the public three weeks before the second wave of a national telephone survey took place. Among those respondents who reported being strongly influenced by Johnson's disclosure, avoidance of PLHA scores were lower at wave II. However, these same individuals were also found to have had very high avoidance scores and strong support for coercive policies of PLHA at wave I. This means that they originally had highly stigmatizing scores and subsequently had the most room for improvement. Individuals who had low avoidance scores at wave I did not reduce their avoidance scores at wave II. Support for coercive policies for PLHA and attitudes of blame toward specific groups for spreading the disease remained unchanged at wave II.

\section{Study methodologies}

Nine studies used a randomized experimental design with either a control or a comparison group (Ashworth et al. 1994; Batson et al. 1997; Bean et al. 1989; Held 1992; Klepp et al. 1997; Perry et al. 1991; Simpson et al. 1998). Three of these studies attempted to measure long-term change, with posttests at 2 months, 12 months, and 3 months (Ashworth et al. 1994; Klepp et al. 1997; Perry et al. 1991). The Bean et al. (1989) interventions utilized a randomized one-way, two-way, and threeway fixed effects design, and the Batson et al. (1997) study was a randomized 2x2x2 factorial design.

Two studies used a pre-posttest design with no control group (Herek and Capitanio 1997; Hue and Kauffman 1998). The Magic Johnson intervention was part of a two-wave panel study conducted using telephone surveys. Researchers selected the participants in the first wave via random digit dialing, and then re-interviewed them for wave II (71percent follow-up rate). Five studies used posttest only designs with varying quantitative and qualitative techniques. Kaleeba et al. (1997) conducted semi-structured interviews, focus groups, key informant interviews, and case studies to evaluate their intervention among a convenience sample of clients. 


\section{Hgrizons}

\section{Review of Interventions to Reduce Stigma Related to Diseases Other Than AIDS}

Given the limited evidence on interventions to combat AIDS stigma, the authors thought it would be instructive to review the effectiveness of interventions to address stigma related to other diseases. Nine studies were identified that aim to reduce stigma related to diseases other than AIDS. They are reviewed on the same characteristics as the AIDS stigma studies: who was the target audience or population, where did the study and intervention take place, what was the intervention, how effective was the intervention, and how was it evaluated (study design and methodology). Table 3 summarizes the results of the nine studies.

\section{Target population}

Despite searching for studies that tested interventions for a wide variety of diseases, eight of the nine non-HIV/AIDS intervention studies identified focused on reducing stigma of mental illness in developed countries (five in the United States, two in Great Britain, and one in Scotland). The ninth study addressed leprosy related stigma in Tanzania. All but one study sought to increase tolerance toward those with the disease and to encourage treatment seeking among different segments of the general population. Four of these studies were conducted among small groups of high school, medical, and psychology students (Esters et al. 1998; Keane 1990; Penn et al. 1994; Shera and Delva-Tauiliili 1996); two were community-based (Brunton 1997; Wolff et al. 1996). Paykel, Hart, and Priest (1998) evaluated a national campaign to reduce the stigma of mental illness and encourage treatment seeking in Great Britain. Van den Broek et al. (1998) assessed the effectiveness of a district level leprosy health education campaign in Tanzania among children, the general public, medical staff and community leaders. Only one study tested the effectiveness of coping skills to reduce stigma among those with mental illness (Link, Mirokznik, and Cullen 1997).

\section{Types of interventions}

The interventions tested are grouped into the same four categories as the AIDS stigma interventions (see Table 2): information-based approaches, coping skills acquisition, counseling approaches, and contact with affected groups.

The five studies that tested information based interventions (Esters, Cooker, and Ittenback 1998; Keane 1990; Paykel, Hart, and Priest 1998; Penn et al. 1994; Van den Broek et al. 1998) all found positive effects. Esters et al. (1998) tested the effectiveness of a three-day health class in a rural U.S. high school on perceptions of mental illness and attitudes toward seeking help for mental health problems. Students who took the class had a more positive attitude toward seeking professional help for mental health problems, and their ideas about mental health improved (e.g., 
who is susceptible, causation, desire for social restriction, threat to society). A second posttest at three months showed that the improvements were sustained. While Keane (1990) found that U.S. medical students who completed an eight-week clerkship in clinical psychology showed increased benevolence toward the mentally ill, the intervention did not reduce negative stereotyping of the mentally ill.

Penn et al. (1994) found that presenting the detailed symptomatology of schizophrenia results in higher stigmatization compared to the label of schizophrenia without the details. However, those subjects who had no previous contact with a mentally ill person were more likely to consider the mentally ill dangerous, and desired greater social distance from them.

Paykel, Hart, and Priest (1998) evaluated Great Britain's five-year Defeat Depression Campaign that aimed to improve attitudes toward the mentally ill through newspaper, magazine, radio, television, and other media advertisements to educate the public about depression and treatment for depression. Two posttests, conducted at three and five years, showed improvement in attitude toward treatment (i.e., that treatment is effective), and more people reported a willingness to consult their general practitioner or a health professional about depression.

Three of the studies used either contact alone or in addition to information, with mixed results (Brunton 1997; Shera and Delva-Tauiliili 1996; Wolff et al. 1996). Both Brunton (1997) and Wolff et al. (1996) evaluated the effects of mental health centers and houses for the mentally ill on the communities' attitudes toward the mentally ill. While members of the communities showed increased tolerance for the mentally ill, there was an increase in the percentage of people who thought that the mentally ill needed to be treated in a hospital.

Link, Mirokznik, and Cullen (1997) evaluated a one-year program for men with a dual diagnosis of substance abuse and mental illness that used information, coping skills acquisition, and counseling techniques. This was the only intervention that attempted to reduce perceptions of stigma among affected individuals, rather than reducing stigma toward affected persons. The treatment program provided information, coping skills acquisition training, and counseling. Although improvements were found in psychiatric symptoms, no changes in perceptions of stigma were observed.

\section{Study methodologies}

All nine interventions were tested with quasi-experimental study designs. Seven of the studies used pre- and posttests (Keane 1990; Link, Mirokznik, and Cullen 1997; Paykel, Hart, and Priest 1998; Brunton 1997; Esters, Cooker, and Ittenback 1998; Shera and Delva-Tauiliili 1996; Wolff et al. 1996), and two used posttest only (Penn et al. 1994; Van den Broek et al. 1998. Brunton (1997), Esters, Cooker, and Ittenback (1998), Shera and Delva-Tauiliili (1996), and Van den Broek et al. (1998) included a comparison or control group. Only the Penn et al. (1994) intervention study randomly selected subjects into intervention groups and did not use a control group. 


\section{Hgrizons}

Overall these studies show that while it is possible to improve tolerance toward those with mental illness and leprosy, combating the multiple layers or dimensions of stigma is a challenge. For example, while community members showed more compassion toward those with mental illness after an intervention, they still thought they needed to be hospitalized. Addressing the complexity of stigma will be important in designing AIDS stigma interventions. 


\section{Summary and Implications}

As mentioned above, stigma is a common human reaction to disease. Throughout history many diseases have carried considerable stigma. The list includes leprosy, tuberculosis, cancer, mental illness, and many STDs. HIV/AIDS is only the latest disease to be stigmatized. Reduction in stigma for some of the infectious diseases can probably be traced to the availability of drugs that have cured, masked, or delayed the onset of final illness or at least treated the worst symptoms of the diseases (Macintyre and Macdonald 2000). Therefore it will be highly instructive to observe the impact of the collection of protease inhibitors on AIDS stigma in multiple settings and cultural contexts.

This review of interventions has helped demonstrate both strengths and weaknesses in the area of interventions that may reduce stigma. However, given the magnitude of this pandemic one could hardly claim that the area of stigma reduction is well studied. This section discusses some of the lessons we can draw in terms of content and methodology, and it outlines gaps for future research.

\section{Implications for Interventions}

- First, while it may be unrealistic to think that we can eliminate stigma altogether, the studies reviewed here show that we can do something about stigma and that it can be reduced through a variety of intervention strategies (including information, counseling, coping skills acquisition, and contact). However, this review is biased toward positive results, and toward programs and researchers that have documented their work. No studies reporting negative results were found. Therefore, we do not know anything about what does not work. While this may be due to publishing bias, another plausible answer is that all programs may have an effect on stigma, although it could be positive or negative.

- Among studies with a control or comparison group that received information alone (basic intervention), adding another intervention strategy such as counseling or coping skill acquisition (experimental arm[s]) was effective in changing attitudes and behaviors. However, as is common in much health communication research, many of the studies tested several different modes of the same strategy (e.g., different approaches to providing information or coping skill acquisition). In general these studies found no differences between intervention groups. For example, in Simpson et al. (1998) the authors used different depths of information and presented it in varying lengths of time to test whether in-depth information or more time taken in presentation had a stronger or weaker effect on acceptance of HIV testing by antenatal women. Although all the intervention groups in this study had higher acceptance rates than the controls, no intervention group was found to have significantly greater acceptance rates than the others, and this lack of difference between groups was echoed in other studies.

- Many of the interventions tried in developing countries were community-based, compared to most of the interventions in the United States, which were aimed at individuals (students or the 


\section{Hgrizons}

assumed at-risk subgroups). This may be partly a reflection of the types of strategies tested, but this preference given to community-based approaches in developing countries may reflect an understanding that stigma must be dealt with at both a collective and individual level. In many parts of sub-Saharan Africa, where many of the studies reviewed took place, everyone is at risk.

- The majority of interventions that took place in developing countries were not evaluated rigorously. Cross-sectional data, non-probability, and small convenience samples were often used to try to measure change in attitudes or beliefs. Several different qualitative methods were employed, such as focus groups and in-depth interviews, which are excellent for providing detailed information about what individuals thought and felt about a program, but their results cannot be generalized to other populations, nor is it possible to measure program impact at a population level with these methods. A very small number of the studies tell how stigma was measured. In two studies, use of a stigma scale provided measures of the concept of tolerance toward an HIV-positive person, but other studies reported tolerance levels such as willingness to sit beside/eat with/share utensils with a PLHA.

- Finally, few studies assessed sustained changes in attitudes and behaviors over time. Most post-intervention tests were conducted immediately after the intervention, and none of the studies appear to have looked at the possible long-term impact of the interventions.

\section{Recommendations for Future Research}

- In terms of gaps in our knowledge of how to reduce stigma, this review can begin to point in a few directions. First, relatively few interventions to reduce AIDS stigma have been conducted (or at least rigorously evaluated, documented, and published) in developing countries. Many more interventions need to be tried. If future research is to benefit and learn from past interventions, the results of these studies need to be widely disseminated.

- Second, not all types of interventions have been tested in all settings or populations. For example, inducing empathy for PLHA through direct contact has proven successful in reducing stigma and increasing positive attitudes in the United States. However, we do not know much about how well this approach works in developing countries. Consider, for example, how many PLHA there are living in many communities in Africa, and yet stigma remains despite their presence.

- The authors were surprised to find only two examples of national level effects (and only one in India that was truly a national campaign) to combat stigma. They expected to find more studies on the effect of mass media campaign on stigma, but if the studies do exist, they have not been documented in the published literature.

- This review tells us that almost everything appears to work, at least in the short term and on a small scale. But we need experiments and programs that scale up efforts to combat stigma. We 
need evidence of multi-channel, comprehensive programs, targeting whole communities, not only health workers or PLHA, whose lives are centered within complex worlds in their own communities and whose reaction to the stigma of AIDS will be influenced by the community's norms. In such comprehensive programs, once stigma has been reduced, does it remain at a low level? In effect "What drives stigma" is an especially important and complex question given the rapidly changing and dynamic situation that surrounds the epidemic. Another gap appears to be the few interventions targeting the young. Finally, as mentioned above, the increased access to drugs in the developing country contexts may have important effects on stigma and must be documented.

To conclude, the ubiquity of stigma and its persistence even in areas where HIV prevalence is high makes it an extraordinarily important yet difficult area of research. One would expect stigma to decrease with increased visibility of HIV, but this is not the case in much of sub-Saharan Africa. Given the fact that AIDS stigma introduces enormous barriers to public health programs-from the denial and silence, to problems associated with disclosure, health seeking behavior, and to the communal violence and breakdown of communication that ended Gugu Dlamini's life-it behooves the international public health community to begin to use more creativity in designing AIDS stigma interventions and to implement them on a significant scale. 


\section{Hgrizons}

\section{References}

Allport, G. 1954. The Nature of Prejudice. New York: Addison Wesley.

Ashworth, C.S. et al. 1994. "An experimental evaluation of an AIDS education intervention for WIC mothers," AIDS Education Prevention April 6(2): 154-62.

Batson, C.D. et al. 1997. "Empathy and attitudes: Can feeling for a member of a stigmatized group improve feelings toward the group?" Journal of Personality and Social Psychology 72: 105-118.

Bean, J. et al. 1989. "Methods for the reduction of AIDS social anxiety and social stigma," AIDS Education and Prevention 1(3): 194-221, Fall.

Boyd, F.M. et al. 1999. "What do pregnant women think about the HIV test? A qualitative study," AIDS Care Feb;11(1): 21-9.

Brewer, M.B. and N. Miller. 1984. "Beyond the contact hypothesis: Theoretical perspective on desegregation," in Groups in contact: The psychology of desegregation, ed. N. Miller and M.B. Brewer. Orlando, FL: Academic Press, pp. 281-302.

Brunton, K. 1997. “Stigma,” Journal of Advanced Nursing 26: 891-898.

Cameron, E. 1993. "Legal rights, human rights and AIDS: The first decade. Report from South Africa 2," AIDS Analysis Africa 3: 3-4.

---. 2000. Breaking the Silence. Opening remarks at International Conference on AIDS, Durban, South Africa, 13,1.

Esters, I., P. Cooker, and R. Ittenback. 1998. "Effects of a unit of instruction in mental health rural adolescents' conceptions of mental illness and attitudes about seeking help," Adolescence 33(130): 469-476.

Gerbert, B.et al. 1991. "Primary care physicians and AIDS: Attitudinal and structural barriers to care," Journal of American Medicine Association 266: 2837-2842.

Goffman, E. 1963. Stigma. Notes on the Management of Spoiled Identity. New York: Simon and Shuster, Inc.

Goldin, C.S. 1994. "Stigmatization and AIDS: Critical issues in public health," Social Science and Medicine 39(9): 1359-1366.

Held, S.L. 1992. "The effects of an AIDS education program on the knowledge and attitudes of a physical therapy class," Physical Therapy March 73(3): 156-64. 
Herek, G.M. 1990. "Illness, stigma, and AIDS," in Psychological Aspects of Serious Illness, ed. P. Costa and G.R. VandenBos. Washington, DC: American Psychological Association, pp. 103-150.

---. 1993. "The relationship of trust to public reactions to AIDS in the United States." Presented at the International Conference on AIDS, Berlin, Germany, 7 -11 June, 11: 914.

Herek, G. M. and J.P. Capitanio. 1997. "AIDS stigma and contact with persons with AIDS: Effects of direct and vicarious contact," Journal of Applied Social Psychology 27(1): 1-36.

Herek, G.M. and J.P. Capitanio. 1998. "Symbolic prejudice or fear of infection? A functional analysis of AIDS-related stigma among heterosexual adults," Basic and Applied Social Psychology. 20(3): 230-241.

Herek, G.M. and E.K. Glunt. 1988. "An epidemic of stigma: Public reactions to AIDS," American Psychology 43: 886-892.

Hue, L. and C. Kauffman. 1998. "Creating positive attitudes toward persons living with HIV/AIDS among young people in hostile environments." Presented at the International Conference on AIDS, Geneva, Switzerland, 28 June-3 July, 12: 970.

Jacoby, A. 1994. "Felt versus enacted stigma: A concept revisited. Evidence from a study of people with epilepsy in remission," Social Science and Medicine Jan 38(2): 269-274.

Jayaraman, K.S. 1998. "Indian state plans compulsory HIV testing, segregation and branding," Nature Medicine 4(4): 378.

Kaleeba, N. et al. 1997. "Participatory evaluation of counseling, medical and social services of The AIDS Support Organization (TASO) in Uganda," AIDS Care 9(1): 13-26.

Kayawe, I., M. Kelly, and R. Baggaley. 1998. "HIV counseling and testing," World Health 51(6): $12-13$

Keane, M. 1990. "Contemporary beliefs about mental illness among medical students: Implications for education and practice," Academic Psychiatry 3(14): 172-177.

Kelly, J.A. et al. 1987. "Stigmatization of AIDS patients by physicians," American Journal of Public Health 77(7): 789-791.

Kerry, K. and C. Margie C. 1996. "Cost effective AIDS awareness program on commercial farms in Zimbabwe." Presented at the International Conference on AIDS, Vancouver, Canada, 712 July, 11(1): 45. 


\section{Hgrizons}

Kiguli, A.R. 1996. "Community initiatives against HIV, care for PWA and care for AIDS affected ones: a multicultural response." Presented at the International Conference on AIDS, Vancouver, Canada, 7-12 July, 11(2): 472.

Kikonyogo, N. et al. 1996. "Sharing HIV/AIDS education in the communities: A Kampala traditional healer's experience." Presented at the International Conference on AIDS, Vancouver, Canada, 7-12 July, 11(2): 339.

King, M.B. 1989. "Prejudice and AIDS: the views and experience of people with HIV infection"," AIDS Care 1(2): 137-143.

Klepp, K.I. et al. 1997. "AIDS education in Tanzania: Promoting risk reduction among primary school children," American Journal of Public Health 87: 1931-1936.

Link, B, J. Mirokznik, and F. Cullen. 1997. "The effectiveness of stigma coping orientations: Can negative consequences of mental illness labeling be avoided?" Journal of Health and Social Behavior 32: 302-320.

Link, Bruce. 2001. "On stigma and its public health implications." Presentation made at the conference Stigma and Global Health: Developing a Research Agenda, Bethesda, Maryland, 5-7 September.

Macintyre, Kate and C. Macdonald. 2000. Implementing Tuberculosis Control in Scotland (19451960): Overcoming stigma at the community level, Wellcome Trust Unit of the History of Medicine. Glasgow University. Working Paper Series.

Macintyre, Kate, Lisanne Brown, and Steven Sosler. 2001. “ 'It's not what you know, but who you knew': Examining the relationship between behavior change and AIDS mortality in Africa," AIDS Education and Prevention 13(2): 160-174.

Malcolm, A.et al. 1998. "HIV-related stigmatization and discrimination: Its forms and contexts," Critical Public Health 8(4): 347-370.

Mechanic, D. 1995. "Sociological dimensions of illness behavior," Social Science and Medicine 41(9): 1207-1216.

Meisenhelder, J.B. and C.L. La Charite. 1989. "Fear and contagion: A stress response to AIDS," Advanced Nursing Science 11(2): 29-38.

Muyinda, H. et al. 1997. "Social aspects of AIDS-related stigma in rural Uganda," Health and Place 3(3): 143-147.

Mwambu, W. 1998. "Knowledge, Attitudes and Practices of Housegirls on HIV/STDs Transmission and Risk Factors." Presented at the International Conference on AIDS, Geneva, Switzerland, 28 June-3 July, 12: 1018-9. 
Mwandha, N.P. and B. Were. 1998. "The Impact of Peer Education in Communities." Presented at the International Conference on AIDS, Geneva, Switzerland, 28 June-3 July, 12: 1170.

Nansubuga, A., F. Aneko F., and L. Kirega. 1996. "Initiated Psycho-social Care by Informal Networking of PWAS." Presented at the International Conference on AIDS, Vancouver, Canada, 7-12 July, 11(1): 242.

North, R.L. and K.H. Rothenberg. 1993. "Partner notification and the threat of domestic violence against women with HIV infection," New England Journal of Medicine, Oct 14; 329(16): 1194-6.

Ogunyombo, D. 1999. "Living with AIDS--an unforgivable crime?," Growing Up 7(3): 8.

Parker, Richard. 2001. "Alternative sexualities and genders in Brazil." Presentation made at the conference Stigma and Global Health: Developing a Research Agenda, Bethesda, Maryland, 5-7 September.

Paykel, E.S., D. Hart, and R.G. Priest. 1998. "Changes in public attitudes to depression during the Defeat Depression Campaign,” The British Journal of Psychiatry 173(12): 519-522.

Penn, D. et al. 1994. "Dispelling the stigma of schizophrenia: What sort of information is best?," Schizophrenia Bulletin 20(3): 567-574.

Perry, S. et al. 1991. "Effectiveness of psychoeducational interventions in reducing emotional distress after human immunodeficiency virus antibody testing" Archives of General Psychiatry 48: 143-147.

Raveis, V.H., K. Siegel, and E. Gorey. 1998. "Factors associated with HIV-infected women's delay in seeking medical care," AIDS Care 10(5): 549-62.

Rothenberg, K.H. and S.J. Paskey. 1995. "The risk of domestic violence and women with HIV infection: Implications for partner notification, public policy, and the law," American Journal of Public Health 85(11): 1569-1576.

Rushing, W.A. 1995. "Moralizing and Scapegoating," in The AIDS Epidemic: Social Dimensions of an Infectious Disease, William A. Rushing. Boulder, Colorado: Westview Press: 163180.

Scrambler, G. 1998. "Stigma and disease: changing paradigms.” Lancet. 352(9133): 1054-1055.

Scrambler, G. and A. Hopkins. 1986. "Being epileptic, coming to terms with stigma." Sociology of Health and Illness. 8: 26-43. 


\section{Hgrizons}

Shera, W.J. and J. Delva-Tauiliili. 1996. "Changing MSW students' attitudes towards the severely mentally ill," Community Mental Health Journal 32(2): 159-69.

Simpson, W.M. et al. 1998. "Uptake and acceptability of HIV testing: A randomized controlled trial of different methods of offering the test," British Medical Journal 316: 262-267.

Sontag, Susan. 1990. Illness as Metaphor and AIDS and Its Metaphors. $1^{\text {st }}$ Edition. New York: Doubleday, Anchor Books.

Soskolne, V. et al. 1993. "Immigrants from a Developing Country in a Western Society: Evaluation of an HIV education program." Presented at the International Conference on AIDS, Berlin, Germany, 6-11 June, 9(2): 777.

Sowell, R.L. et al. 1997. "Resources, Stigma, and Patterns of Disclosure in Rural Women with HIV Infection," Public Health Nursing 14(5): 302-312.

Sowell, R. et al. 1999. "Experiences of violence in HIV-positive women in the south-eastern Was it hyphenated in the title? United States of America," Journal of Advanced Nursing 30(3): 606-615.

UNAIDS. 2000a. “AIDS Epidemic Update.” UNAIDS/00.44E.

---. 2000b. "HIV and AIDS-related stigmatization, discrimination and denial: forms, contexts and determinants." UNAIDS Best Practice Collection. UNAIDS/00.16E.

Van den Broek, J. et al. 1998. "Evaluation of a sustained 7-year health education campaign on leprosy in Rufiji District, Tanzania," Leprosy Review 69: 57-74.

Venkataraman, R. et al. 1996. "Using Docu-drama Films on Life Stories of PLWHAs as Media Strategy to Change Attitudes." Presented at the International Conference on AIDS, Vancouver, Canada, 7-12 July, 11(1): 46.

Weinberger, M. et al. 1992. "Physicians' attitudes and practices regarding treatment of HIVinfected patients," Southern Medical Journal 85: 683-686.

Wolff, G. et al. 1996. "Public education for community care. A new approach," British Journal of Psychiatry 168(4): 441-447.

Wyness, M.A., I. Goldstone, and T. Trussler. 1996. "Outcomes of an undergraduate HIV/AIDS nursing elective: Insightful learning to promote quality care." Presented at the International Conference on AIDS, Vancouver, Canada, 7-12 July, 11(1): 21.

Zierler, S. et al. 2000. "Violence victimization after HIV infection in a US probability sample of adultpatients in primary care," American Journal of Public Health 90(2): 208-215. 
Table 1 Summary of HIV/AIDS stigma interventions

\begin{tabular}{|c|c|c|c|c|}
\hline $\begin{array}{l}\text { Author/Date } \\
\text { Sample }\end{array}$ & Objective of Study & Intervention/Measures & Design/Analysis & Results \\
\hline $\begin{array}{l}\text { Ashworth et al., } 1994 \\
\text { U.S./ Georgia } \\
\text { WIC Mothers }(95 \% \\
\text { black) } \\
n=217\end{array}$ & $\begin{array}{l}\text { To improve attitudes } \\
\text { of Women, Infants, } \\
\text { and Children (WIC) } \\
\text { mothers toward } \\
\text { PLHA. }\end{array}$ & $\begin{array}{l}\text { Information: } \\
\text { Videotape on AIDS (about } \\
15 \text { minutes); black nurse } \\
\text { educator individually } \\
\text { presented AIDS information. } \\
\text { Measured by belief that } \\
\text { PLHA should be isolated. }\end{array}$ & $\begin{array}{l}\text { Randomized } \\
\text { experimental design } \\
\text { with control and two } \\
\text { experimental groups; } \\
\text { pre- and posttest, and } \\
\text { second posttest at two } \\
\text { months. }\end{array}$ & $\begin{array}{l}\text { Both experimental groups showed } \\
\text { higher tolerance for PLHA as } \\
\text { compared to controls at first } \\
\text { posttest, these effects did not differ } \\
\text { across treatments. At second } \\
\text { posttest all three groups the same. }\end{array}$ \\
\hline $\begin{array}{l}\text { Batson et al., } 1997 \\
\text { U.S./Kansas } \\
\text { Young women in } \\
\text { introductory } \\
\text { psychology course } \\
\mathrm{n}=96\end{array}$ & $\begin{array}{l}\text { To assess effect of } \\
\text { empathy on attitudes } \\
\text { toward PLHA } \\
\text { generally and a young } \\
\text { woman with AIDS } \\
\text { specifically. }\end{array}$ & $\begin{array}{l}\text { Contact: } \\
\text { Mock pilot radio broadcast } \\
\text { testimonial of female PLHA } \\
\text { with different acquisitions of } \\
\text { HIV (blood transfusion and } \\
\text { sexual behavior). Measured } \\
\text { empathic feelings (tested } \\
\text { high versus low empathy) for } \\
\text { the PLHA and attitudes } \\
\text { toward PLHA. }\end{array}$ & $\begin{array}{l}\text { Randomized-block } 2 \times \\
2 \times 2 \text { factorial design, } \\
\text { pre-/posttest ( } 12 \text { per } \\
\text { group). }\end{array}$ & $\begin{array}{l}\text { Empathy scores higher in high- } \\
\text { empathy group than in low; higher } \\
\text { empathy for victim-not-responsible } \\
\text { than for victim-responsible but both } \\
\text { significant. Inducing empathy for a } \\
\text { member of a stigmatized group } \\
\text { (young woman with AIDS) can } \\
\text { improve attitudes toward group as a } \\
\text { whole. }\end{array}$ \\
\hline $\begin{array}{l}\text { Bean et al., } 1989 \\
\text { U.S. } \\
\text { Psychology } \\
\text { students/volunteers } \\
n=58\end{array}$ & $\begin{array}{l}\text { To reduce AIDS } \\
\text { anxiety/fear and } \\
\text { improve altruism. }\end{array}$ & $\begin{array}{l}\text { Coping skill acquisition: } \\
\text { Experimenter-guided } \\
\text { imagery, three variations } \\
\text { tested } \\
-\quad \text { Mater imagery. } \\
\text { - } \quad \text { Empathy instruction. } \\
-\quad \text { Implosion (coping skills } \\
\quad \text { for anxiety). }\end{array}$ & $\begin{array}{l}\text { Randomized one-way } \\
\text { fixed effects design } \\
\text { with one control and } \\
\text { three experimental } \\
\text { groups. Posttest. }\end{array}$ & $\begin{array}{l}\text { The three levels of imagery reduced } \\
\text { AIDS anxiety and increased } \\
\text { altruism as compared to control, but } \\
\text { no differential effects between } \\
\text { treatment groups. }\end{array}$ \\
\hline
\end{tabular}

* Only abstracts available 


\begin{tabular}{|c|c|c|c|c|}
\hline $\begin{array}{l}\text { Author/Date } \\
\text { Sample }\end{array}$ & Objective of Study & Intervention/Measures & Design/Analysis & Results \\
\hline $\begin{array}{l}\text { Bean et al., } 1989 \\
\text { U.S. } \\
\text { Psychology } \\
\text { students/volunteers } \\
\mathrm{n}=53\end{array}$ & $\begin{array}{l}\text { To reduce AIDS } \\
\text { anxiety/fear and } \\
\text { improve attitude } \\
\text { toward PLHA. }\end{array}$ & $\begin{array}{l}\text { Coping skill acquisition: } \\
\text { Improvisational vs. } \\
\text { controlled role play. }\end{array}$ & $\begin{array}{l}\text { Randomized three- } \\
\text { way fixed-effects } \\
\text { experimental design } \\
\text { with one control, two } \\
\text { experimental groups, } \\
\text { one stratified by } \\
\text { subject gender, the } \\
\text { other stratified by } \\
\text { subject and } \\
\text { experimenter gender. }\end{array}$ & $\begin{array}{l}\text { Improvisational group reported } \\
\text { more positive attitude toward } \\
\text { PLHA, higher scores on granting } \\
\text { rights to PLHA. Intervention did not } \\
\text { reduce measured fear. } \\
\text { Experimenters with same sex } \\
\text { subjects had stronger role play } \\
\text { effects than with the opposite sex. }\end{array}$ \\
\hline $\begin{array}{l}\text { Bean et al., } 1989 \\
\text { U.S. } \\
\text { Psychology } \\
\text { students/volunteers } \\
\mathrm{n}=192\end{array}$ & $\begin{array}{l}\text { To reduce AIDS } \\
\text { anxiety/fear and } \\
\text { improve attitude } \\
\text { toward PLHA. }\end{array}$ & $\begin{array}{l}\text { Information, counseling, } \\
\text { contact: Combinations of } \\
\text { AIDS/unsafe behavior facts, } \\
\text { social contact, case studies, } \\
\text { AIDS psychology, factual } \\
\text { presentation with brief group } \\
\text { desensitization }\end{array}$ & $\begin{array}{l}\text { Randomized two-way } \\
\text { fixed effects } \\
\text { experimental design } \\
\text { stratified by gender. } \\
\text { One control and five } \\
\text { treatment groups. }\end{array}$ & $\begin{array}{l}\text { All treatment groups had higher } \\
\text { knowledge scores and lower anxiety } \\
\text { scores as compared to control } \\
\text { group. The group that had brief } \\
\text { desensitization showed lower score } \\
\text { for social restriction of PLHA. }\end{array}$ \\
\hline $\begin{array}{l}\text { Held, } 1992 \\
\text { US } \\
\text { Physical therapy } \\
\text { students } \\
\text { Convenience sample } \\
\mathrm{n}=103\end{array}$ & $\begin{array}{l}\text { To reduce AIDS fear, } \\
\text { increase health } \\
\text { workers' willingness to } \\
\text { treat. }\end{array}$ & $\begin{array}{l}\text { Information,counseling, } \\
\text { coping skill acquisition: Four } \\
\text { hour educational unit: factual } \\
\text { information, resolving } \\
\text { negative feelings. }\end{array}$ & $\begin{array}{l}\text { Randomized } \\
\text { experimental design, } \\
\text { one control, one } \\
\text { experimental group. } \\
\text { Posttest at one week. }\end{array}$ & $\begin{array}{l}\text { Increased HIV/AIDS knowledge, } \\
\text { increase in positive attitudes toward } \\
\text { PLHA, increase in willingness to } \\
\text { treat PLHA. }\end{array}$ \\
\hline
\end{tabular}

* Only abstracts available 


\begin{tabular}{|c|c|c|c|c|}
\hline $\begin{array}{l}\text { Author/Date } \\
\text { Sample }\end{array}$ & Objective of Study & Intervention/Measures & Design/Analysis & Results \\
\hline $\begin{array}{l}\text { Herek et al., } 1997 \\
\text { U.S. } \\
\text { General population } \\
\mathrm{n} 1=538, \mathrm{n} 2=382, \\
\text { Intervention } \mathrm{n}=40 \\
\text { oversample of Blacks } \\
\mathrm{n} 1=607, \mathrm{n} 2=420\end{array}$ & $\begin{array}{l}\text { To measure } \\
\text { stigmatizing attitudes } \\
\text { of the general US } \\
\text { population. Through } \\
\text { 'natural' intervention } \\
\text { also assessed } \\
\text { reduction of AIDS } \\
\text { stigma among general } \\
\text { US population. }\end{array}$ & $\begin{array}{l}\text { Contact (vicarious and } \\
\text { direct): } \\
\text { Earvin "Magic" Johnson"s } \\
\text { disclosure of having HIV as } \\
\text { intervention. Measured by } \\
\text { self-report impact on } \\
\text { attitudes. Also measured } \\
\text { stigma change for } \\
\text { respondents who reported } \\
\text { direct contact with a PLHA } \\
\text { between Wave I and Wave II } \\
(\mathrm{n}=40) \text {. }\end{array}$ & $\begin{array}{l}\text { Two-wave national } \\
\text { telephone interviews } \\
\text { using random-digit } \\
\text { dialing. Earvin } \\
\text { Johnson's disclosure } \\
\text { took place three weeks } \\
\text { before Wave II. }\end{array}$ & $\begin{array}{l}\text { Intent to avoid PLHA decreased for } \\
\text { respondents who reported high level } \\
\text { of influence from Johnson's } \\
\text { disclosure ( } p<.05) \text {. This group also } \\
\text { had high avoidance scores at outset. } \\
\text { Direct contact with PLHA was } \\
\text { associated (but not significant) with } \\
\text { less support for coercive AIDS } \\
\text { policies, less blame for, and less } \\
\text { avoidance of, PLHA. }\end{array}$ \\
\hline $\begin{array}{l}\text { Hue et al., } 1998^{*} \\
\text { Jamaica } \\
\text { Youth } \\
\mathrm{n}=320\end{array}$ & $\begin{array}{l}\text { To improve attitudes } \\
\text { toward PLHA among } \\
\text { youth by encouraging } \\
\text { compassion and } \\
\text { acceptance of PLHA. }\end{array}$ & $\begin{array}{l}\text { Information: Peer education } \\
\text { and workshop: pre-workshop } \\
\text { assignments, street interviews } \\
\text { to examine fears, one-on-one } \\
\text { conversations with PLHA, } \\
\text { and concerts. Measured by } \\
\text { willingness to sit next to, eat } \\
\text { with, visit and reduce } \\
\text { isolation. }\end{array}$ & $\begin{array}{l}\text { Pre/post-questionnaire, } \\
\text { focus groups, and } \\
\text { direct observation. }\end{array}$ & $\begin{array}{l}\text { Significant increase }(\mathrm{p}<.001) \text { in } \\
\text { positive attitudes toward PLHA on } \\
\text { all three willingness measures, and } \\
\text { reduced percent wanting isolation } \\
\text { for PLHA. }\end{array}$ \\
\hline $\begin{array}{l}\text { Kaleeba et al., } 1997 \\
\text { Uganda } \\
\text { Clients of (TASO) } \\
n=232\end{array}$ & $\begin{array}{l}\text { To improve life of } \\
\text { PLHA through } \\
\text { promotion of } \\
\text { disclosure and } \\
\text { acceptance by family } \\
\text { and community. }\end{array}$ & $\begin{array}{l}\text { Information, counseling: } \\
\text { One-on-one counseling } \\
\text { approach. This is an } \\
\text { evaluation of an on-going } \\
\text { PLHA support organization. }\end{array}$ & $\begin{array}{l}\text { Convenience sample; } \\
\text { semi-structured } \\
\text { interviews, focus } \\
\text { groups, } 24 \text { key } \\
\text { informant interviews, } \\
\text { case studies of clients. }\end{array}$ & $\begin{array}{l}90 \% \text { reported revealing serostatus to } \\
\text { someone. Family support } 79 \% \text {, } \\
\text { community acceptance } 76 \% \text {, HIV } \\
\text { knowledge } 98 \% \text {, condom use } 33 \% \text {, } \\
\text { and abstinence } 45 \% \text {. }\end{array}$ \\
\hline $\begin{array}{l}\text { Kerry et al., } 1996^{*} \\
\text { Zimbabwe/ Harare } \\
\text { Commercial farmers } \\
\text { and employees, } \\
\text { communities } \\
\text { n not known }\end{array}$ & $\begin{array}{l}\text { To implement a cost- } \\
\text { effective AIDS } \\
\text { awareness and stigma } \\
\text { reduction program } \\
\text { among commercial } \\
\text { farmers and } \\
\text { employees. }\end{array}$ & $\begin{array}{l}\text { Information, peer education: } \\
\text { Work-based peer education } \\
\text { using individual } \\
\text { communication, group } \\
\text { meetings and workshops. } \\
\text { IEC consisted of videos, } \\
\text { drama, AIDS literature, and } \\
\text { free condoms. }\end{array}$ & No details provided. & $\begin{array}{l}\text { Reports a decline in stigma as } \\
\text { evidenced by more open discussion. } \\
\text { Also high levels of AIDS } \\
\text { awareness, higher acceptance of } \\
\text { condoms, and movement toward } \\
\text { self-help and home care. }\end{array}$ \\
\hline
\end{tabular}

* Only abstracts available 


\begin{tabular}{|c|c|c|c|c|}
\hline $\begin{array}{l}\text { Author/Date } \\
\text { Sample }\end{array}$ & Objective of Study & Intervention/Measures & Design/Analysis & Results \\
\hline $\begin{array}{l}\text { Kiguli, } 1996^{*} \\
\text { Uganda/Kampala } \\
\text { (TASO) } \\
\text { Community } \\
\text { n not known }\end{array}$ & $\begin{array}{l}\text { To improve } \\
\text { community attitudes } \\
\text { about HIV and care } \\
\text { for PLHA and those } \\
\text { affected by HIV; } \\
\text { promote shared } \\
\text { confidentiality. }\end{array}$ & $\begin{array}{l}\text { Coping skill acquisition, } \\
\text { counseling: Community } \\
\text { planning and evaluation } \\
\text { system. Through local } \\
\text { leaders an assessment of the } \\
\text { effect of AIDS. Test of } \\
\text { shared confidentiality, } \\
\text { improved home care. }\end{array}$ & No details provided. & $\begin{array}{l}\text { Reports stigma dying away, people } \\
\text { are changing their sexual behavior } \\
\text { and how to negotiate safer sex. }\end{array}$ \\
\hline $\begin{array}{l}\text { Kikonyogo et al., } \\
1996^{*} \\
\text { Uganda/Kampala } \\
\text { Community } \\
\text { n not known }\end{array}$ & $\begin{array}{l}\text { To decrease PLHA } \\
\text { isolation and increase } \\
\text { community cohesion } \\
\text { through use traditional } \\
\text { healers as community } \\
\text { educators for AIDS } \\
\text { (THECA). }\end{array}$ & $\begin{array}{l}\text { Information, counseling: } \\
\text { THECA group was started to } \\
\text { be community educators for } \\
\text { AIDS knowledge, attitudes } \\
\text { and practices. Community } \\
\text { education and counseling, } \\
\text { targeting youth and women. }\end{array}$ & $\begin{array}{l}\text { Implies a one-year } \\
\text { follow up or measure } \\
\text { of some sort but } \\
\text { details not provided. }\end{array}$ & $\begin{array}{l}\text { Reports change in community } \\
\text { knowledge, attitudes and practices, } \\
\text { higher trust and attendance at clinic, } \\
\text { condom demand is up, PLHA } \\
\text { getting better family care and report } \\
\text { safer sex. }\end{array}$ \\
\hline $\begin{array}{l}\text { Klepp et al., } 1997 \\
\text { Tanzania/ } 2 \text { districts } \\
\text { Primary school } \\
\text { children } \\
\mathrm{n}=814\end{array}$ & $\begin{array}{l}\text { To test effect of } \\
\text { education program } \\
\text { that aims to reduce } \\
\text { children's risk of HIV } \\
\text { infection and to } \\
\text { improve their } \\
\text { tolerance of and care } \\
\text { for PLHA. }\end{array}$ & $\begin{array}{l}\text { Information, coping skill } \\
\text { acquisition: Provided factual } \\
\text { information, students created } \\
\text { posters, wrote/performed } \\
\text { songs/poetry, small group } \\
\text { discussions, performed plays, } \\
\text { and role play. }\end{array}$ & $\begin{array}{l}\text { Randomized } \\
\text { controlled community } \\
\text { trial with baseline, } \\
\text { intervention, and 12- } \\
\text { month follow-up. }\end{array}$ & $\begin{array}{l}\text { Average score on attitudes toward } \\
\text { PLHA scale significantly improved } \\
\text { in the intervention group as } \\
\text { compared to the control group. }\end{array}$ \\
\hline $\begin{array}{l}\text { Mwambu, 1998* } \\
\text { Tanzania } \\
\text { Housegirls, other } \\
\text { members of these } \\
\text { household } \\
\text { (employers) } \\
\mathrm{n}=2,500\end{array}$ & $\begin{array}{l}\text { To improve AIDS } \\
\text { awareness and } \\
\text { behavior change skills } \\
\text { among housegirls and } \\
\text { employers. }\end{array}$ & $\begin{array}{l}\text { Information, coping skill } \\
\text { acquisition: Educational } \\
\text { videos, posters, leaflets, } \\
\text { newsletters, and condoms. } \\
\text { Peer education for groups. } \\
\text { All in addition to usual } \\
\text { services provided by center. }\end{array}$ & $\begin{array}{l}\text { No information } \\
\text { provided. }\end{array}$ & $\begin{array}{l}\text { Increase in HIV/STDs knowledge } \\
(98 \%) \text {, reported desire to change } \\
\text { behavior ( } 75 \%) \text {, empowered to } \\
\text { negotiate safer sex, partner } \\
\text { notification, counseling, and } \\
\text { voluntary screening }(50 \%) \text {. Increase } \\
\text { in people coming to center for } \\
\text { services and becoming clients. } \\
\text { Shyness and stigma minimized. }\end{array}$ \\
\hline
\end{tabular}

* Only abstracts available 


\begin{tabular}{|c|c|c|c|c|}
\hline $\begin{array}{l}\text { Author/Date } \\
\text { Sample }\end{array}$ & Objective of Study & Intervention/Measures & Design/Analysis & Results \\
\hline $\begin{array}{l}\text { Mwandha et al., } \\
1998^{*} \\
\text { Uganda } \\
\text { Community served by } \\
\text { TASO } \\
\text { n not known }\end{array}$ & $\begin{array}{l}\text { To assess the impact } \\
\text { of peer education to } \\
\text { improve acceptance of } \\
\text { PLHA in communities } \\
\text { through TASO. }\end{array}$ & $\begin{array}{l}\text { Information, contact: PLHA } \\
\text { testimonies, music, dance, } \\
\text { and dramas, backed by a } \\
\text { counselor and medical } \\
\text { practitioner. Sensitised } \\
\text { communities with: pre- } \\
\text { contemplation, safer sex, } \\
\text { demystifying false beliefs, } \\
\text { positive living, assessed } \\
\text { communities' attitudes } \\
\text { toward PLHA. }\end{array}$ & $\begin{array}{l}\text { No information } \\
\text { provided. }\end{array}$ & $\begin{array}{l}\text { Wide spread AIDS awareness, } \\
\text { behavior change, reduction in } \\
\text { stigma and discrimination of PLHA, } \\
\text { better coping for PLHA, change in } \\
\text { community attitude toward TASO, } \\
\text { and more PLHA organizations } \\
\text { formed. }\end{array}$ \\
\hline $\begin{array}{l}\text { Nansubuga et al., } \\
1996^{*} \\
\text { Uganda/Gulu } \\
\text { Community } \\
\text { n not known }\end{array}$ & $\begin{array}{l}\text { To promote } \\
\text { acceptance of PLHA } \\
\text { in the community } \\
\text { through shared } \\
\text { confidentiality. } \\
\text { To improve psycho- } \\
\text { social care through } \\
\text { informal networking. }\end{array}$ & $\begin{array}{l}\text { Contact, counseling: Self } \\
\text { help community intervention } \\
\text { to bring PLHA together for } \\
\text { support, education for } \\
\text { communities, and upholding } \\
\text { PLHA morale. No } \\
\text { measurement details } \\
\text { provided. }\end{array}$ & $\begin{array}{l}\text { No information } \\
\text { provided. }\end{array}$ & $\begin{array}{l}\text { Reports that communities have } \\
\text { developed a positive attitude toward } \\
\text { PLHA. Reduced social distance } \\
\text { between PLHA and community. }\end{array}$ \\
\hline $\begin{array}{l}\text { Perry et al., } 1991 \\
\text { U.S. } \\
\text { Asymptomatic at-risk } \\
\text { adults testing for HIV } \\
\mathrm{n}=307\end{array}$ & $\begin{array}{l}\text { To examine the } \\
\text { effectiveness of } \\
\text { psychoeducational } \\
\text { interventions in } \\
\text { reducing emotional } \\
\text { distress after HIV } \\
\text { testing. }\end{array}$ & $\begin{array}{l}\text { Information, counseling: } \\
\text { Standard post-HIV test } \\
\text { counseling, a three session } \\
\text { interactive video, or } 6 \text { one- } \\
\text { hour stress prevention } \\
\text { programs (SPT). }\end{array}$ & $\begin{array}{l}\text { Randomized } \\
\text { longitudinal design, no } \\
\text { control, and three } \\
\text { experimental groups. } \\
\text { Pretest before HIV } \\
\text { testing and posttest at } \\
\text { three months. }\end{array}$ & $\begin{array}{l}\text { Seronegative subjects' distress level } \\
\text { decreased for all groups. No } \\
\text { differential treatment effects. } \\
\text { Seropositive subjects in SPT group } \\
\text { had reduced distress as compared to } \\
\text { other two groups. Distress levels did } \\
\text { not increase for other two groups. }\end{array}$ \\
\hline
\end{tabular}

* Only abstracts available 


\begin{tabular}{|c|c|c|c|c|}
\hline $\begin{array}{l}\text { Author/Date } \\
\text { Sample }\end{array}$ & Objective of Study & Intervention/Measures & Design/Analysis & Results \\
\hline $\begin{array}{l}\text { Simpson et al., } 1998 \\
\text { Scotland/Edinburgh } \\
\text { Pregnant women } \\
n=3,024\end{array}$ & $\begin{array}{l}\text { To assess uptake and } \\
\text { acceptability of HIV } \\
\text { testing among prenatal } \\
\text { women offered the } \\
\text { test. }\end{array}$ & $\begin{array}{l}\text { Information, counseling: } \\
\text { Four combinations of } \\
\text { leaflets, duration of } \\
\text { discussion, and midwives } \\
\text { who discussed HIV in } \\
\text { different depths of detail. All } \\
\text { women in experimental } \\
\text { groups offered HIV test. The } \\
\text { all blood test pamphlet aimed } \\
\text { to normalize HIV. Anxiety } \\
\text { scale used to assess stigma. }\end{array}$ & $\begin{array}{l}\text { Randomized } \\
\text { controlled trial, one } \\
\text { control, four } \\
\text { experimental groups, } \\
\text { only posttest. }\end{array}$ & $\begin{array}{l}\text { Uptake rates for control was } 6 \% \text {, } \\
\text { intervention was } 35 \% \text {. All } \\
\text { intervention groups had } \\
\text { significantly higher rates as } \\
\text { compared to control group. Effects, } \\
\text { including satisfaction and anxiety, } \\
\text { did not differ by type of } \\
\text { intervention. }\end{array}$ \\
\hline $\begin{array}{l}\text { Soskolne et al., 1993* } \\
\text { Israel } \\
\text { Adult immigrants, } \\
\text { PLHA, community } \\
\mathrm{n}=300\end{array}$ & $\begin{array}{l}\text { To encourage positive } \\
\text { attitudes toward HIV- } \\
\text { positive persons, } \\
\text { increase knowledge, } \\
\text { and promote safe } \\
\text { behaviors among } \\
\text { Ethiopian immigrants } \\
\text { in Israel. }\end{array}$ & $\begin{array}{l}\text { Information: Thirty } \\
\text { community members trained } \\
\text { to act both as health } \\
\text { educators and cultural } \\
\text { mediators, lectures with } \\
\text { posters, audio cassettes and } \\
\text { leaflets with positive } \\
\text { messages stressed. Used } \\
\text { questionnaire, but no } \\
\text { measurement details } \\
\text { provided. }\end{array}$ & $\begin{array}{l}\text { Randomly selected } \\
\text { sample for three- } \\
\text { month post-education } \\
\text { test. }\end{array}$ & $\begin{array}{l}\text { Those who attended the educational } \\
\text { sessions given by the } 30 \text { trained } \\
\text { community members had less } \\
\text { misperceptions, better knowledge of } \\
\text { modes of prevention, and more } \\
\text { positive attitudes toward PLHA and } \\
\text { toward condom use. }\end{array}$ \\
\hline $\begin{array}{l}\text { Venkataraman et al., } \\
1996^{*} \\
\text { India } \\
\text { National, community } \\
\text { n not known }\end{array}$ & $\begin{array}{l}\text { To improve attitudes } \\
\text { toward PLHA in India } \\
\text { through TV } \\
\text { documentary of a } \\
\text { PLHA's life. }\end{array}$ & $\begin{array}{l}\text { Information, contact } \\
\text { (vicarious): Mass media IEC } \\
\text { campaign to foster } \\
\text { acceptance of PLHA and to } \\
\text { normalize HIV; a PLHA's } \\
\text { life was turned into a 28- } \\
\text { minute documentary video } \\
\text { and telecast on National TV, } \\
\text { volunteers and general public } \\
\text { from various communities } \\
\text { participated. }\end{array}$ & $\begin{array}{l}\text { Focus groups } \\
\text { conducted to test } \\
\text { efficacy of } \\
\text { intervention as a } \\
\text { means of reducing } \\
\text { isolation. No other } \\
\text { design information } \\
\text { provided. }\end{array}$ & $\begin{array}{l}\text { Focus groups report that this media } \\
\text { effort increases acceptance and } \\
\text { decreases stigma. Volunteers more } \\
\text { willing to work in AIDS field, } \\
\text { CBOs and NGOs willing to work } \\
\text { with PLHA and use docu-dramas, } \\
\text { policy makers sensitized. }\end{array}$ \\
\hline
\end{tabular}

* Only abstracts available 


\begin{tabular}{|l|l|l|l|l|}
\hline $\begin{array}{l}\text { Author/Date } \\
\text { Sample }\end{array}$ & Objective of Study & Intervention/Measures & Design/Analysis & Results \\
\hline Wyness et al., 1990* & $\begin{array}{l}\text { To improve future } \\
\text { health care personnel's } \\
\text { attitudes toward } \\
\text { PLHA. }\end{array}$ & $\begin{array}{l}\text { Information, contact, coping } \\
\text { skill acquisition: An } \\
\text { HIV/AIDS elective class for } \\
\text { undergraduate students } \\
\text { Nursing students } \\
\text { nnot known }\end{array}$ & $\begin{array}{l}\text { Focus groups done at } \\
\text { end of course and } \\
\text { telephone interviews } \\
\text { at six months. }\end{array}$ & $\begin{array}{l}\text { Students reexamined their attitudes, } \\
\text { stigmas, and fears about PLHA } \\
\text { when taught by HIV/AIDS health } \\
\text { professionals and PLHA. Small } \\
\text { group teaching, in a climate that } \\
\text { promotes reflection and sharing of } \\
\text { prevention and care and } \\
\text { thoughts and feeling, is essential }\end{array}$ \\
\hline
\end{tabular}

* Only abstracts available 
Table 2 Types of interventions

\begin{tabular}{|c|c|c|c|c|}
\hline Type & $\begin{array}{l}\text { Information-based } \\
\text { approaches }\end{array}$ & $\begin{array}{l}\text { Coping skill } \\
\text { acquisition }\end{array}$ & $\begin{array}{l}\text { Counseling } \\
\text { approaches }\end{array}$ & $\begin{array}{l}\text { Contact with } \\
\text { affected groups }\end{array}$ \\
\hline Definition & $\begin{array}{l}\text { Information- or fact- } \\
\text { based written and/or } \\
\text { verbal communication. }\end{array}$ & $\begin{array}{l}\text { Learning a coping } \\
\text { behavior. }\end{array}$ & $\begin{array}{l}\text { Providing support } \\
\text { for positive } \\
\text { behavior. }\end{array}$ & $\begin{array}{l}\text { Interaction between } \\
\text { affected groups and } \\
\text { general public. }\end{array}$ \\
\hline Examples & $\begin{array}{l}\text {-Information packet or } \\
\text { leaflet } \\
\text {-Classroom-type } \\
\text { factual presentation } \\
\text {-Media advertisements } \\
\text {-Peer education } \\
\text {-Guided group } \\
\text { discussions }\end{array}$ & $\begin{array}{l}\text {-Role play } \\
\text {-Master imagery } \\
\text {-Reframing and } \\
\text { relaxing techniques } \\
\text {-Group } \\
\text { desensitization } \\
\text {-Scripting }\end{array}$ & $\begin{array}{l}\text {-One-on-one } \\
\text { counseling } \\
\text {-Support groups }\end{array}$ & $\begin{array}{l}\text {-Live testimonials } \\
\text {-Interaction with } \\
\text { PLHA } \\
\text {-Visualization of } \\
\text { being a PLHA }\end{array}$ \\
\hline
\end{tabular}

* Only abstracts available 
Table 3 Summary of non-HIV/AIDS stigma interventions

\begin{tabular}{|c|c|c|c|c|}
\hline $\begin{array}{l}\text { Author/Date } \\
\text { Sample }\end{array}$ & $\begin{array}{l}\text { Objectives of } \\
\text { Study }\end{array}$ & Intervention/Measures & Design/Analysis & Results \\
\hline $\begin{array}{l}\text { Brunton, } 1997 \\
\text { Scotland } \\
\text { Community } \\
\mathrm{n} \geq 250\end{array}$ & $\begin{array}{l}\text { Reducing stigma } \\
\text { toward mental } \\
\text { illness through } \\
\text { increased contact. }\end{array}$ & $\begin{array}{l}\text { Information, contact: } \\
\text { Opening a community mental } \\
\text { health base (MHB) in the } \\
\text { center of a town. } 13 \text { stigma- } \\
\text { related questions. }\end{array}$ & $\begin{array}{l}\text { Houses directly surrounding } \\
\text { MHB surveyed via mail-return } \\
\text { questionnaires ( } 31 \% \text { response } \\
\text { rate), prior to opening, then at } \\
\text { post-6 months. Comparison } \\
\text { survey of comparable town } \\
\text { nearby without MHB for both } \\
\text { surveys. }\end{array}$ & $\begin{array}{l}\text { Conflicting results: both } \\
\text { control and comparison } \\
\text { groups had lower feelings } \\
\text { of embarrassment by } \\
\text { mentally ill people post- } \\
\text { opening. Substantial } \\
\text { increase in both control } \\
\text { and comparison agreeing } \\
\text { with the statement "all } \\
\text { mentally ill people should } \\
\text { be treated in a hospital." }\end{array}$ \\
\hline $\begin{array}{l}\text { Esters et al., } \\
1998 \\
\text { U.S. } \\
\text { Adolescents in high } \\
\text { school } \\
n=40\end{array}$ & $\begin{array}{l}\text { Changing } \\
\text { conceptions of } \\
\text { mental illness and } \\
\text { attitudes about } \\
\text { seeking help. }\end{array}$ & $\begin{array}{l}\text { Information: } \\
\text { Three days of education: } \\
\text { video, supplemental } \\
\text { information with sources of } \\
\text { local help, descriptions of } \\
\text { different types of helpers, and } \\
\text { reality of associated stigma. } \\
\text { Opinions about Mental } \\
\text { Illness Questionnaire, and } \\
\text { Fischer-Turner Pro-Con } \\
\text { Attitude Scale. }\end{array}$ & $\begin{array}{l}\text { Non-randomized with one } \\
\text { intervention, one control; pre- } \\
\text { and posttest; first posttest on } \\
\text { last day of treatment second } \\
\text { posttest } 12 \text { weeks later. }\end{array}$ & $\begin{array}{l}\text { Students' attitudes more } \\
\text { favorable toward seeking } \\
\text { professional help for } \\
\text { mental problems. Students' } \\
\text { ideas about mental illness } \\
\text { became more like those of } \\
\text { mental health } \\
\text { professionals. } \\
\text { Improvements did not } \\
\text { decrease at second posttest. }\end{array}$ \\
\hline
\end{tabular}




\begin{tabular}{|c|c|c|c|c|}
\hline $\begin{array}{l}\text { Author/Date } \\
\text { Sample }\end{array}$ & $\begin{array}{l}\text { Objectives of } \\
\text { Study }\end{array}$ & Intervention/Measures & Design/Analysis & Results \\
\hline $\begin{array}{l}\text { Keane, } 1990 \\
\text { U.S. } \\
\text { Medical students } \\
\mathrm{n}=46\end{array}$ & $\begin{array}{l}\text { Beliefs about } \\
\text { mental illness } \\
\text { among medical } \\
\text { students }\end{array}$ & $\begin{array}{l}\text { Information: } \\
\text { An eight-week academic and } \\
\text { clinical course in psychiatry. }\end{array}$ & $\begin{array}{l}\text { Pretest and posttest were } \\
\text { Opinion About Mental Illness } \\
\text { questionnaire and Derogatis' } \\
\text { Symptom Checklist. }\end{array}$ & $\begin{array}{l}\text { Posttest scores were higher } \\
\text { for increasing funding and } \\
\text { improving care for severely } \\
\text { mentally ill. More disagreed } \\
\text { with needing a high fence } \\
\text { and guards for mental } \\
\text { institutions. Higher scores } \\
\text { for believing that mental } \\
\text { illness arose from } \\
\text { interpersonal experiences. } \\
\text { More disagreed with } \\
\text { mentally ill as more likely } \\
\text { to commit crimes than } \\
\text { others. Stigma ratings did } \\
\text { not change significantly. }\end{array}$ \\
\hline $\begin{array}{l}\text { Link et al., } \\
1997 \\
\text { U.S. } \\
\text { Men with dual } \\
\text { diagnoses of mental } \\
\text { illness and substance } \\
\text { abuse } \\
n=84\end{array}$ & $\begin{array}{l}\text { Perceptions of } \\
\text { stigma and the } \\
\text { association between } \\
\text { stigma and } \\
\text { depressive } \\
\text { symptoms. }\end{array}$ & $\begin{array}{l}\text { Information, coping skill } \\
\text { acquisition, counseling: } \\
\text { A one-year treatment } \\
\text { program for substance abuse. } \\
\text { Measured whether stigma } \\
\text { had enduring effects on } \\
\text { feelings of wellbeing. }\end{array}$ & $\begin{array}{l}\text { Pre- and posttest conducted for } \\
\text { a one-year treatment program } \\
\text { for substance abuse. }\end{array}$ & $\begin{array}{l}\text { No change in perceptions of } \\
\text { stigma, coping orientations, } \\
\text { or in recall of rejection } \\
\text { experiences during the } \\
\text { treatment year. No decrease } \\
\text { in association between } \\
\text { stigma and depression after } \\
\text { treatment: even though } \\
\text { there was marked } \\
\text { improvement in psychiatric } \\
\text { symptoms, no perceived } \\
\text { stigma and rejections were } \\
\text { unchanged. }\end{array}$ \\
\hline
\end{tabular}

* Only abstracts available 


\begin{tabular}{|c|c|c|c|c|}
\hline $\begin{array}{l}\text { Author/Date } \\
\text { Sample }\end{array}$ & Objectives of Study & Intervention/Measures & Design/Analysis & Results \\
\hline $\begin{array}{l}\text { Paykel et al., } \\
1998 \\
\text { Great Britain } \\
\text { General population } \\
\mathrm{n} \sim 2000 \text { for each } \\
\text { survey }\end{array}$ & $\begin{array}{l}\text { Reduce stigma of } \\
\text { mental illness and } \\
\text { encourage } \\
\text { treatment-seeking. }\end{array}$ & $\begin{array}{l}\text { Information: } \\
\text { Newspaper, magazine, radio, } \\
\text { TV and other media used to } \\
\text { educate public about } \\
\text { depression and treatment } \\
\text { thereof. }\end{array}$ & $\begin{array}{l}\text { Pre- and two posttests (at three } \\
\text { and five years) using face to } \\
\text { face interview questionnaires. } \\
\text { This was a 5-year national } \\
\text { campaign therefore no control } \\
\text { group. }\end{array}$ & $\begin{array}{l}\text { Attitude toward treatment } \\
\text { improved (i.e., treatment is } \\
\text { effective); more people } \\
\text { would consult general } \\
\text { practitioner (GP) doctor or } \\
\text { health professional. If } \\
\text { depressed, attitude about } \\
\text { depression being a medical } \\
\text { condition improved. } \\
\text { "Anyone can suffer } \\
\text { depression" question was } \\
\text { always very high. }\end{array}$ \\
\hline $\begin{array}{l}\text { Penn et al., } \\
1994 \\
\text { U.S. } \\
\text { University } \\
\text { psychology students } \\
\mathrm{n}=329\end{array}$ & $\begin{array}{l}\text { Reduce stigma of } \\
\text { schizophrenia. }\end{array}$ & $\begin{array}{l}\text { Information: } \\
\text { Series of read vignettes } \\
\text { portraying depression, and } \\
\text { combination of labeling of } \\
\text { schizophrenia (label), } \\
\text { symptom presentation } \\
\text { (symptom), and post- } \\
\text { hospitalization home care- } \\
\text { taking (aftercare). } \\
\text { Measurement scales } \\
\text { consisted of: social distance, } \\
\text { dangerousness to others, } \\
\text { affective reaction, and skill } \\
\text { assessment. }\end{array}$ & $\begin{array}{l}\text { Students randomly selected } \\
\text { into one of the six vignettes } \\
\text { and groups of } 15-20 \text { were } \\
\text { tested at a time. Posttest } \\
\text { administered and students } \\
\text { were debriefed. Data stratified } \\
\text { by subjects having had } \\
\text { previous contact with mentally } \\
\text { ill person. }\end{array}$ & $\begin{array}{l}\text { Greater negative affective } \\
\text { reactions found for label } \\
\text { with symptom and for } \\
\text { symptom alone than for } \\
\text { depression. Higher life skills } \\
\text { associated with label alone } \\
\text { than for depression, label } \\
\text { with symptom, or symptom } \\
\text { alone. No differences by } \\
\text { vignette type found in } \\
\text { stigma rating for those } \\
\text { subjects who reported } \\
\text { previous contact with a } \\
\text { mentally ill person. No } \\
\text { social distance or } \\
\text { dangerousness differences } \\
\text { were found for any vignette. }\end{array}$ \\
\hline
\end{tabular}

* Only abstracts available 


\begin{tabular}{|c|c|c|c|c|}
\hline $\begin{array}{l}\text { Author/Date } \\
\text { Sample }\end{array}$ & Objectives of Study & Intervention/Measures & Design/Analysis & Results \\
\hline $\begin{array}{l}\text { Shera et al., } 1996 \\
\text { U.S. } \\
\text { Masters in Social } \\
\text { Work (MSW) } \\
\text { students } \\
\mathrm{n}=53\end{array}$ & $\begin{array}{l}\text { Improving MSW } \\
\text { students' attitudes } \\
\text { toward the severely } \\
\text { mentally ill (MI). }\end{array}$ & $\begin{array}{l}\text { Information, contact: } \\
\text { Students enrolled in mental } \\
\text { health concentration. } 30 \\
\text { minute video, structured } \\
\text { interviews with a MI person, } \\
\text { and one class about } \\
\text { subjective experience of MI. }\end{array}$ & $\begin{array}{l}\text { Non-randomized, } 1 \text { control ( } \mathrm{n} \\
=13 \text { ) and } 2 \text { interventions }(\mathrm{n}= \\
22 \text { and } 28) \text {. Authors wrote } \\
\text { their own } 14 \text { item survey } \\
\text { instrument for pre- and } \\
\text { posttest (done at } 4 \text { weeks } \\
\text { post). }\end{array}$ & $\begin{array}{l}\text { Intervention groups had a } \\
\text { more positive attitude } \\
\text { toward severely mentally ill, } \\
\text { mostly attributable to the } \\
\text { interview contact. }\end{array}$ \\
\hline $\begin{array}{l}\text { Van den Broek et } \\
\text { al., } 1998 \\
\text { Rufiji District, } \\
\text { Tanzania } \\
\text { Children } \mathrm{n}=1,120, \\
\text { general public } \mathrm{n}= \\
534, \text { medical staff } \mathrm{n} \\
=96, \text { community } \\
\text { leaders } \mathrm{n}=47\end{array}$ & $\begin{array}{l}\text { Reduce stigma of } \\
\text { Leprosy through } \\
\text { health education } \\
\text { campaign. }\end{array}$ & $\begin{array}{l}\text { Information: } \\
\text { Seven-year intensive health } \\
\text { education campaign. } \\
\text { Evaluated using a semi- } \\
\text { structured questionnaire. } \\
\text { Stigma measured by five } \\
\text { hypothetical questions (e.g., } \\
\text { would you shake hands with } \\
\text { someone with Leprosy. }\end{array}$ & $\begin{array}{l}\text { Quasi-experimental case- } \\
\text { control, stratified by } \\
\text { urban/rural. Urban areas } \\
\text { purposively sampled, rural } \\
\text { areas randomly selected. } \\
\text { Posttest of seven-year } \\
\text { intensive health education } \\
\text { campaign. Control was a } \\
\text { neighboring district. }\end{array}$ & $\begin{array}{l}\text { School children: higher } \\
\text { willingness to play with and } \\
\text { share food with leprosy } \\
\text { victim; no differences in } \\
\text { mention of stigmatizing way } \\
\text { of contracting leprosy. } \\
\text { General public: less mention } \\
\text { of stigmatizing way of } \\
\text { contracting leprosy. Medical } \\
\text { staff: higher willingness to } \\
\text { shake hands with leprosy } \\
\text { victim, but no other } \\
\text { differences. }\end{array}$ \\
\hline
\end{tabular}

* Only abstracts available 


\begin{tabular}{|l|l|l|l|l|}
\hline $\begin{array}{l}\text { Author/Date } \\
\text { Sample }\end{array}$ & Objectives of Study & Intervention/Measures & Design/Analysis & Results \\
\hline $\begin{array}{l}\text { Wolff et al., } \\
1996\end{array}$ & $\begin{array}{l}\text { Improve attitudes } \\
\text { toward mentally ill }\end{array}$ & $\begin{array}{l}\text { Information, contact: } \\
\text { Community education } \\
\text { campaign: didactic } \\
\text { component (info sheet and } \\
\text { videa); Bocial component } \\
\text { n not known }\end{array}$ & $\begin{array}{l}\text { (social events and social } \\
\text { overtures from staff); and } \\
\text { mixed component (formal } \\
\text { reception \& informal } \\
\text { toward MI conducted in two } \\
\text { communities before opening } \\
\text { of supported houses for } \\
\text { mentally ill. Posttest: attitude } \\
\text { survey repeated in both areas } \\
\text { and patient contact with } \\
\text { neighbors was recorded. }\end{array}$ & $\begin{array}{l}\text { Decrease in intervention } \\
\text { group's fear and exclusion } \\
\text { based on contact with } \\
\text { accepts. Increased reported } \\
\text { Intervention group more } \\
\text { likely to make contact with } \\
\text { staff and patients on all } \\
\text { levels (casual to } \\
\text { friendships). No change in } \\
\text { feeling need for social } \\
\text { control of MI. No change in } \\
\text { goodwill toward MI. }\end{array}$ \\
\hline
\end{tabular}




\section{Hgrizons}

Horizons is a global operations research program designed to:

- Identify and test potential strategies to improve HIV/AIDS prevention, care, and support programs and service delivery.

- Disseminate best practices and utilize findings with a view toward scaling up successful interventions.

For more information, please contact:

Horizons Program, Communications Unit 4301 Connecticut Avenue, NW Suite 280 Washington, DC 20008 USA

Tel: 202-237-9400

Fax: 202-237-8410

Email: horizons@pcdc.org

www.popcouncil.org/horizons/horizons.html

\section{Q Population Council}

Horizons is implemented by the Population Council in collaboration with

- International Center fr Researb on Women (ICPN)

- International HIV/AIDS Alliance

· Program fr Appropriate Tednnology in Health (PATH)

- The University of Alabama at Birmingham

- Tulane University 